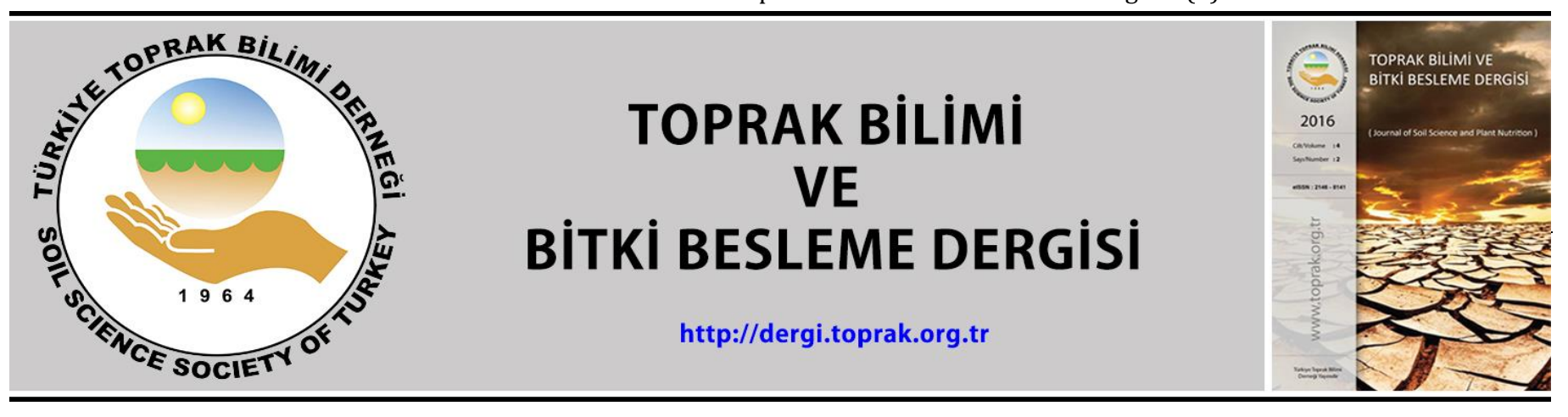

\title{
Yarı nemli ılıman iklim koşullarında farklı eğim ve farklı arazi örtüsü altında toprak gelişimi ve $\beta$-glikosidaz enzim aktivitesi değişimi
}

\author{
Aylin Erkoçak ${ }^{1, *}$, Orhan Dengiz ${ }^{2}$ \\ ${ }^{1}$ Karadeniz Tarımsal Araștırma Enstitüsü, Samsun \\ ${ }^{2}$ Ondokuz Mayıs Üniversitesi, Ziraat Fakültesi, Toprak Bilimi ve Bitki Besleme Bölümü, Samsun
}

\begin{abstract}
Özet
Toprak içerisinde yer alan mikroorganizmalar, bitki gelişmesi için gerekli olan besin elementlerinin döngüsünde görev aldıkları için toprak verimliliğinin önemli unsurlarının yanı sıra toprakta meydana gelen pek çok kimyasal değişimin içinde aktif rol almaktadırlar. Topraktaki mikrobiyal aktivitenin büyük bir kısmı enzimlerin aktivitelerinin ölçülmesiyle belirlenmektedir. Bu çalışmanın amacı yarı nemli ılıman iklim koşulları altında aynı ana materyal, farklı eğim ve arazi kullanımlarında farklı toprakların gelişimlerinin ortaya konulması ve $\beta$-glikosidaz enzim aktivitesi değişimini incelemektir. Bu çalışma, Samsun-Bafra karayolunun güneyinde, Engiz Beldesine bağlı Dağköy mevkii alanı içerisinde farklı fizyografik ünitelerin yer aldığı bazaltik ana materyal üzerinde oluşmuş topraklarda yürütülmüsstür. Topraklar Typic Haplustert ve Lithic Ustorthent olarak sınıflandırılmıștır. Çalış̧a alanına ait toprakların biyolojik özelliklerinin ortaya konulması amacıyla $\beta$-glikosidaz enzim aktivitesi değerlendirilmiş ve Güneybatı-Kuzeydoğu doğrultu hattı boyunca dört profil açılmış ve açılan profillerden alınan toprak örneklerinin $\beta$-glikosidaz enzim aktivitesinin 4.9-98.9 $\mu \mathrm{g}$ p-nitrofenol $\mathrm{g}^{-1}$ kuru top. arasında değiștiği belirlenmiștir. Ayrıca Güneybatt-Kuzeydoğu hattı boyunca $\beta$-glikosidaz enzim aktivitesi ile farklı profiller, arazi kullanımı ve yükseklik arasındaki istatistiksel ilişsi incelendiğinde farklı profillerin ve farklı yüksekliklerin topraktaki $\beta$-glikosidaz enzim aktivitesi üzerine etkisinin \%1 düzeyinde önemli olduğu $(\mathrm{P}=0.000<0.01)$, farklı arazi kullanım şekillerinin ise topraktaki $\beta$-glikosidaz enzim aktivitesi üzerine etkisinin önemsiz olduğu $(\mathrm{P}=$ $0.670>0.05$ ) belirlenmiștir.
\end{abstract}

Anahtar Kelimeler: Toprak mikroorganizmaları, $\beta$-glikosidaz enzim aktivitesi, profil, arazi kullanımı, yükseklik.

\section{Variation of $\beta$-glucosidase enzyme activity and soil development with different slope and land cover under semi moist humid climate conditions}

\begin{abstract}
Microorganisms that live in soil not only play an active role in many chemical changes that take place in the soil but also are important components of soil fertility because they work in the cycle of the nutrients required for plant development. Most of the microbial activity in the soil is determined by measuring the activities of the enzymes. The aim of this study is to examine the changes in $\beta$-glucosidase enzyme aktivities and soil development formed on the same parent material, but with different slopes, land cover and land use under semihumid climatic conditions. It was carried out on the soils formed on the basaltic parent material in different physiographic positions within the Dağköy area of Engiz District, which is located at the south of the Samsun-Bafra Highway. In this study, $\beta$-glycosidase enzyme activity was assessed in order to detect the biological properties of the soils in the study area. It was determined that the $\beta$-glycosidase enzyme activity of the soil samples taken from the four profiles classified as Typic Haplustert and Lithic Ustorthent and selected on southwest and northeast direction changed between 4.9-98.9 $\mu \mathrm{g}$ pnitrophenol. In addition, According to the statistical relationship between $\beta$-glycosidase enzyme activity and different profiles, land uses/land covers and elevations along the southwest and northeast transect, different profiles and different elevations were found to be important at $1 \%$ level of effect on $\beta$-glycosidase enzyme activity in the soils. Also, it was determined that the effect of different land use and land cover patterns on the activity of $\beta$-glycosidase enzyme in the soil was insignificant as statistically.
\end{abstract}

Keywords: Soil microorganisms, $\beta$-glycosidase enzyme activity, profile, land use, elevation.

(C) 2019 Türkiye Toprak Bilimi Derneği. Her Hakkı Saklıdır

* Sorumlu yazar:

Tel. : : $\quad 03622560514$

E-posta : aylin.erkocak@tarim.gov.tr
Geliş Tarihi

Kabul Tarihi
26 Ekim 2017

10 Ocak 2019
e-ISSN

DOI
2146-8141

10.33409/tbbbd.595121 


\section{Giriş}

Toprak mikroorganizmaları gerek toprak gerekse de bitkilerin beslenmesi açısından önemli yer tutan bitki besin elementlerini kayaçlardan-minerallerden açığa çıkartmaları nedeniyle önemlidirler. Toprakta yaşayan makro ve mikroorganizmaların özellikle organik maddelerin ve mineral-kayaçların parçalanmasında önemli rolleri bulunmakta ve bu canlılar bazen mekanik bazen de kimyasal etki meydana getirerek kayaçmineralleri ayrıştırarak toprak oluşumuna yardımcı olmaktadırlar. Toprak mikroorganizmaları topraklara ilave edilen bitkisel ve hayvansal atıkların mineralizasyonu ve bitki besin elementlerinin biyokimyasal dönüşümü gibi birçok sürece aktif olarak katıldığı gibi toprakların verimliliği üzerine de önemli etkileri bulunmaktadır. Bu nedenle toprakların kalitesi, verimlilik düzeyi, bitki beslenmesi açısından alınması gereken önlemler ortaya konulurken toprakların fiziksel, kimyasal, biyolojik ve minerolojik özellikleri birlikte ele alınmaktadır (Schinner, 1986).

Toprak verimliliği yalnızca toprağın fiziksel koşulları ve besin maddesi düzeyine bağlı olmayıp biyolojik olayların yoğunluğu ile de ilgilidir. Toprak, biyolojik olarak dengede bulunan bir sistemdir. Ancak bu denge, çevresel özelliklerin bozulması nedeniyle toprak verimliliğinden sorumlu olan mikroflora ve onun aktivitelerinin değişimine neden olabilir (Arcak ve ark., 1996). Toprak enzimleri, toprağın diğer biyolojik özellikleri ile yakın bir ilişkiye sahip olup, topraktaki mineralizasyon işlemlerinde önemli rol oynamaktadır (Frankberger ve Dick, 1983; Tate, 1987). Toprakların toplam biyokimyasal aktivitesi enzimler tarafından katalizlenen bir seri reaksiyonu kapsamaktadır. Bu katalitik enzimlerin büyük bir kısmı, toprak mikroorganizmalarının besin maddelerini parçalamak amacıyla dışarıya salgıladıkları enzimlerdir. Bunlar hem toprak çözeltisinde serbest halde hem de toprakların organik ve inorganik bileșenlerine bağlı halde bulunabilmekte Rowell ve ark. (1973) ve canlı hücrelerin yıkımı sonucu oluşmaktadırlar. Tarım topraklarının çok yakın mesafelerde dahi çok farklı özellikler göstermesi; biyolojik, kimyasal ve fiziksel özelliklerin birbirinden bağımsız davranmaları ve biyolojik özelliklerin çok geniş dağılım ve aktivite göstermeleri gibi birçok neden, biyolojik özelliklerin analitik yaklaşımında yetersiz kalmaktadır. Bu nedenlerle tarım yapılan toprakların mikrobiyolojik özelliklerinin belirlenmesi toprakta cereyan eden süreçlerin daha iyi anlaşılmasında önemli katkılar sağlayacaktır.

Topraktaki besin döngüsü biyokimyasal, kimyasal ve fizikokimyasal reaksiyonları kapsamakta ve birçok biyokimyasal olay; toprak canlıları, bitki kökleri ile mikroorganizmalardan kaynaklanan toprak enzimleri aracılı̆̆ıyla yürütülmektedir (Tabatabai, 1982). Bu çalışma ile de farklı topografik pozisyonlarda yer alan bazaltik ana materyal üzerinde oluşmuş toprakların $\beta$-glikosidaz enzim aktivitesi ile yükselti ve arazi kullanımı arasındaki ilişkilerin belirlenmesi ve ele alınan bu parametrelerin toprak oluşumuna etkilerinin ortaya konulması amaçlanmıştır.

\section{Materyal ve Yöntem}

\section{Araştırma Alanının Genel Tanımı}

Engiz Çayı havzası Karadeniz Bölgesi’nin Orta Karadeniz Bölümünde, Bafra Ovasının kuzeyinde, Samsun ili sınırları içerisinde yer alır. Araştırma sahası Engiz Çayı havzası aşağı çı̆̆ırında, Dağköy mevkii alanı içerisinde kalan, Güneybatı-Kuzeydoğu (CD) doğrultu kesiti ve deniz seviyesinden $20 \mathrm{~m}$ ile $300 \mathrm{~m}$ arasında yükselti değişkenliğinde bulunmaktadır (Şekil 1).
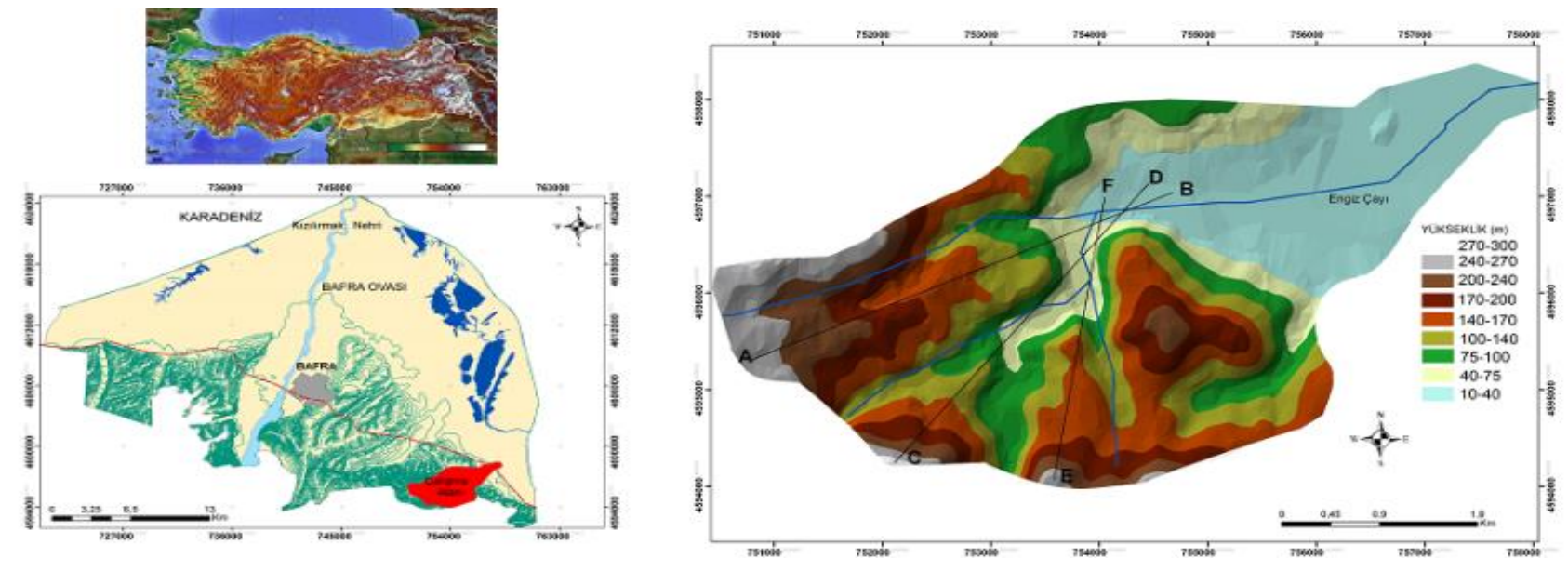

Şekil 1. Çalışma alanı lokasyon ve yükseltiye bağlı kesit haritası 
Sahanın oluşum ve gelişiminde Engiz Çayı büyük rol oynamaktadır. Araştırma sahası ve yakın çevresinde yüzeylenen en geniş birim Yenikonak formasyonudur. Volkano sedimanter kayaçlardan oluşmaktadır. Büyük çoğunluğu tüf, tüfit, bazalt, kumlu kireçtaşı ve marn ara seviyeli kumtaşı-şeyl ardalanmasından oluşmaktadır. Yenikonak formasyonu içerdiği Nummulites helveticus Kaufman, Discocyclina nummulitice Gümbel ve Assilina sp. gibi fosiller nedeniyle Lütesiyen (Orta Eosen) olarak yaşlandırılmıştır (Gedik ve Korkmaz 1984). Dikkate alınan bazalt ana materyali üzerinde oluşan topraklarda mera alanları ile kuru tarım yapılan alanlar yer almakta olup çok az olsa da meşelerden oluşan ormanlık alanlar mevcuttur. Mera alanlarında yaygın olan bașlıca otsu familyalar şunlardır; lahanagiller (Cruciferae), buğdaygiller (Gramineae), maydonozgiller (Umbelliferae), papatyagiller (Compositae), baklagiller (Fabaceae), gülgiller (Rosaceae). Kuru tarım yapılan alanlarda da çoğunlukla buğday tarımı yapılmaktadır.

Engiz Çayı Havzasının iklim özelliklerini açıklamak amacıyla sahanın iklimini karakterize eden meteoroloji istasyonları belirlenmiştir. Araştırma sahası içerisinde ölçüm istasyonu bulunmamaktadır. Bu yüzden saha çevresindeki istasyonlar esas alınmıştır. Araştırma sahasında yılın en soğuk ayı Şubat'tır (5.6ㅇ). En sıcak aylar ise Temmuz ve Ağustos aylarıdır (22.6으). Yılın dört ayında (Aralık, Ocak, Şubat, Mart) ortalama sıcaklıklar $10^{\circ} \mathrm{C}$ 'nin altında kalırken Nisan ayından itibaren yükselmektedir. Araştırma sahasında ortalama yağış miktarı $800 \mathrm{~mm}$ civarındadır. Araştırma sahası uzun yıllar aylık yağış ortalamaları ise en düşük yağış miktarı Temmuz (30.9 mm) ve Ağustos (42.2 mm) aylarında, en yüksek yağış miktarı ise Ekim (101.6 mm) ayındadır. Yağışın mevsimlere göre dağılışı incelendiğinde en fazla yağışın sonbahar mevsiminde en az yağışın ise yazın düştüğü görülmektedir. Buna göre çok düzenli olmasa da yağışların bütün yıla dağıldığını söylemek mümkündür.

Arazide yapılan ön arazi keşif çalışması yanı sıra alanda farklı topografya ve bazalt ana materyal üzerinde oluşmuş farklı toprak yerleri sayısal topografik harita üzerine koordinatları aktarılmıștır. Arazide daha önce ön arazi keşfi ve büro çalışmalarıyla belirlenen profil çukur yerleri arazide GPS aleti kullanılarak yerleri belirlenmiș ve bu noktalarda profil çukurları açılmıștır. Açılan her bir profil çukurundan horizon esasına göre (1.5-2 m açılan toprak kuyuları içerisinde oluşmuş farklı özelliklere sahip katmanlardan) toprak örneklemeleri yapılarak, laboratuvara getirilmiş ve analiz ön işlemlerine tabi tutulmuştur. Analizlere hazır hale getirilen topraklarda fiziksel, kimyasal, biyolojik, verimlilik, morfolojik, minerolojik ve jeokimyasal analizler yapılmıştır. Morfolojik çalışmalarda Soil Survey Staff (1993)'den yararlanılmıştır.

Profillerin morfolojik incelemesinde \% 10'luk $\mathrm{HCl}$ çözeltisi, geniş yüzeyli bıçak, saf su, Japon tipi renk skalası Oyama ve Takehara (1967) ve profil tanımlama kartı kullanılmıştır. Toprakların morfolojik tanımlamaları için açılan her profil Soil Survey Manual (1993) tarafından belirtilen usuller esas alınarak incelenmiștir. Horizonların tanımı ve adlandırılması ise Soil Survey Staff (1999)'a göre yapılmıştır. Laboratuvar analizleri için açılan profillerden horizon esasına göre bozulmuş ve bozulmamış toprak örnekleri alınmıştır. Laboratuvara getirilen örnekler kurutularak $2 \mathrm{~mm}$ 'lik elekten elenmiş ve analizlerde kullanılmak üzere plastik saklama kaplarında depolanmıştır. Güneybatı-Kuzeydoğu (CD) kesiti üzerinde dört adet profil açılmış ve her bir profile ait horizonlardan horizon esasına göre bozulmuş ve bozulmamış toprak örneklemeleri yapılmıștır (Şekil 2).

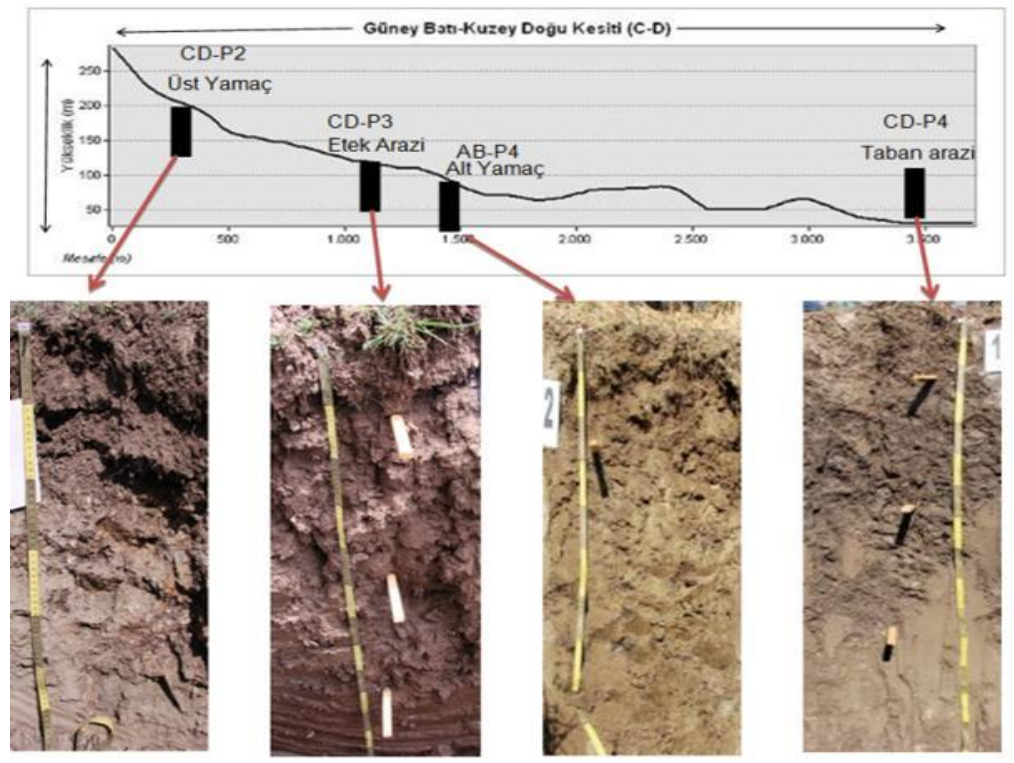

Şekil 2. Güneybatı-Kuzeydoğu doğrultusunda yer alan farklı topografik pozisyonda açılan profiller 


\section{Fiziksel ve Kimyasal Analizler}

Bünye (Tekstür): Bozulmuş toprak örneklerinde Bouyoucos (1951); Katyon değişim kapasitesi: pH sı 8.2' ye ayarlı sodyum asetat ( $\mathrm{NaOAc}$ ) ve $1 \mathrm{~N}$ amonyum asetat $\left(\mathrm{NH}_{4} \mathrm{OAc}\right)$ kullanılarak Rhoades (1986), Değișebilir katyonlar ( $\mathrm{Na}$ ve $\mathrm{K}$ ): $\mathrm{pH}$ ' sı 8.2'ye ayarl amonyum asetat $\left(\mathrm{NH}_{4} \mathrm{OAc}\right.$ ) kullanılarak Rhoades (1986), $\mathrm{Ca}+\mathrm{Mg}$ ise katyon değișim kapasitesi ile toplam değișebilir sodyum ve potasyum arasındaki farktan belirlenmiștir. Kireç; serbest karbonatların tayininde Scheibler kalsimetresi kullanılarak Soil Survey Staff (1993), toprak reaksiyonu $(\mathrm{pH})$; saturasyon çamurunda pH metre kullanılarak Soil Survey Labrotory (1992, 2004), elektriksel iletkenlik; saturasyon çamurunda kondaktivimetre aleti kullanılarak Soil Survey Labrotory (1992, 2004), organik madde: Walkley-Black yönteminin Jackson tarafından modifiye edilmiş şekli ile yapılmıştır (Jackson, 1958).

\section{及-Glikosidaz Aktivitesi}

Toprak örneklerinin $\beta$-Glikosidaz aktivitesi Eivazi ve Tabatabai (1988) tarafından bildirildiği şekilde belirlenmiştir. $\mathrm{Bu}$ amaçla, toprak örnekleri üzerine modifiye Universal tampon çözeltisi (pH 6) ve pnitrofenil $\beta$-D-gliko pyranoside çözeltisi ilave edilerek, 1 saat süre ile $37{ }^{\circ} C^{\prime}$ de inkübasyona bırakılmıştır. İnkübasyon sonunda oluşan p-nitrofenol $410 \mathrm{~nm}$ 'de spektrofotometre de belirlenerek, elde edilen sonuçlar $\mu \mathrm{g}$ p-nitrofenol (p-NF) g-1 kuru toprak cinsinden ifade edilmiştir.

\section{İstatistiksel Analizler}

Çalışma alanına ait toprak örneklerinde $\beta$-glikosidaz enzim aktivitesi ile farklı profiller, arazi kullanımı ve yükseklik arasındaki ilişkileri belirlemek amacıyla SPSS 17.0 paket programı kullanılmıştır.

\section{Bulgular ve Tartışma}

\section{Toprakların Fiziksel, Kimyasal Özellikleri ve Sınıflaması}

Güneybatı-Kuzeydoğu kesiti üzerinde dört adet profil açılmış ve her bir profile ait horizonlardan horizon esasına göre toprak örneklemeleri yapılmıştır. Kesit üzerinde yer alan toprakların bazı fiziko-kimyasal analiz sonuçları Çizelge 1'de verilmiştir. CD-P4 nolu profil taban arazi üzerinde oluşmuş düz düze yakın eğimli, derin topraklardır. Tüm profil kil bünyeli olup, kil \% 56.2 ile \% 78.2 arasında değişmektedir. Bu durum toprakların doygunluk durumlarını doğrudan etkilemeleri nedeniyle özellikle kil miktarının derinlikle artışı, toprakların sature olma durumlarını da arttırmaktadır. KDK'ları yüzeyde organik madde miktarı ve kil içeriği nedeniyle 42.8 cmol.kg-1 olmasına karşın derinlere doğru bu miktar düşüş göstermektedir. Bu durum organik madde miktarı içinde geçerli olup yüzeyde \% 1.65 olmasına karşın $65 \mathrm{~cm}$ den sonra \% 0.14'e düşmektedir. Toprak reaksiyonu hafif alkalin ve pH değerleri 7.05 ile 8.25 arasında değişmektedir. Kireç profilde çok az miktarda olup, yüzeyde \% 0.20 iken derinde bir miktar artarak \% 2.67 olmaktadır. Topraklarda baskın değişebilir katyonlar Ca ve Mg iyonlarıdır. Topraklarda tuzluluk ve alkalilik problemi görülmemektedir.

AB-P4 kodlu profil alt yamaç arazileri üzerinde, hafif dik eğimli (\%6-12), sığ topraklardır. Bu toprakların bulunduğu araziler orman arazisinde açma yapılması sonrası kuru tarım alanı olarak kullanılmaktadır. Bu durum özellikle uygun olmayan işlemeli tarım yapılması (eğime paralel) nedeniyle toprakların taşınımına neden olduğu orman altı toprak derinliği $(45 \mathrm{~cm})$ ile karşılaştırıldığında daha da belirgin hale gelmektedir. Yüzey toprakları killi tın bünyeli iken altında yer alan yoğun bir alterasyona uğramış ana materyal içerisinde bünye kumlu tına dönüşmektedir. KDK'ları yüzeyde organik madde miktarı ve kil içeriği nedeniyle 42.9 cmol.kg-1 olmasına karşın $24 \mathrm{~cm}^{\prime}$ den sonra $15.4 \mathrm{cmol}^{-k^{-1}}$ düşmektedir. Benzer şekilde organik madde miktarı içinde geçerli olup yüzeyde \% 2.35 olmasına karşın yüzey altı katmanda \%0.55’e düşmektedir. Toprak reaksiyonu hafif alkalin olup, pH değerleri 7.87 ile 8.04 arasında değişmektedir. Kireç profilde çok az miktardadır. Topraklarda baskın değişebilir katyonlar Ca ve Mg iyonlarıdır. Topraklarda tuzluluk ve alkalilik problemi görülmemektedir.

CD-P3 kodlu profil alt ve üst yamaç araziler arasında yer alan hafif eğime sahip etek arazi üzerinde yer almaktadır. Üzerinde genellikle mera örtüsü bulunduran bu arazilerdeki topraklar, derin ve ağır bünyelidirler. Kil profilde \% 40.3 ile \% 68.5 arasında değişmektedir. Bu durum CD-P4 kodlu profilde olduğu gibi toprakların doygun olma durumlarını doğrudan etkilemeleri nedeniyle özellikle kil miktarının derinlikle artışı, toprakların sature olma durumlarını da arttırmaktadır. KDK'ları yüzeyde organik madde miktarı ve kil içeriği nedeniyle $42.80 \mathrm{cmol}^{\mathrm{kg}}{ }^{-1}$ olmasına karşın derinlere doğru bu miktar düşüş göstermektedir. Bu durum organik madde miktarı içinde geçerli olup yüzeyde \% 1.71 olmasına karşın $48 \mathrm{~cm}$ den sonra \% 0.59'a düşmektedir. Toprak reaksiyon hafif alkalin ve pH değerleri 7.05 ile 7.96 arasında değişmektedir. Kireç profilde çok az miktarda olup, yüzeyde \% 0.29 iken derinde bir miktar artarak \% 1.37 olmaktadır. 
Topraklarda baskın değișebilir katyonlar Ca ve Mg iyonlarıdır. Topraklarda tuzluluk ve alkalilik problemi görülmemektedir. CD-P2 kodlu profil güneybatı-kuzeydoğu kesiti üzerinde deniz seviyesinden $185 \mathrm{~m}$ ile en yüksekte yer alan profil olup, fizyografik arazi şekli yamaç arazilerdir. Yüzey örtüsü çok zayıf olması ve dik eğimli olmaları nedeniyle erozyon şiddeti fazla, bu nedenle de topraklar çok sı̆̆ derinliğe sahiptirler. Yüzey toprakları kil tın bünyeli iken altında yer alan yoğun bir alterasyona uğramış ana materyal içerisinde bünye kumlu tına dönüşmektedir. KDK'ları yüzeyde organik madde miktarı ve kil içeriği nedeniyle $34.46 \mathrm{cmol.kg}^{-1}$ olmasına karşın 16 cm'den sonra 11.09 cmol.kg-1 düşmektedir. Benzer şekilde organik madde miktarı içinde geçerli olup yüzeyde \% 2.25 olmasına karşın yüzey altı katmanda \% 0.42'e düşmektedir. Toprak reaksiyonu hafif alkalin olup pH değerleri 6.93 ile 7.03 arasında değişmektedir. Kireç profilde çok az miktarda belirlenmiştir. Topraklarda baskın değişebilir katyonlar Ca ve Mg iyonlarıdır. Topraklarda tuzluluk ve alkalilik problemi görülmemektedir.

AB-P4 ve CD-P2 nolu profiller eğimli araziler üzerinde yer alan bu topraklar, özellikle yeterince bitki örtüsünce kaplı olmamaları ve yanlış işlemeli tarım uygulamaları sonucu erozyona maruz kalmaları nedeniyle, yeterince pedogenetik sürece sahip olamayan, sığ topraklardır. Bu toprakların yüzeyde genellikle bir ochric epipedon ve yüzey altında $50 \mathrm{~cm}$ derinlik içerisinde bir lithic kontak dışında her hangi bir tanı horizonu bulunmamaktadır. Topraklar yamaç arazi üzerinde yer almaları nedeniyle orthent alt ordosuna nem rejiminden dolayı ustorthent ve Lithic Ustorthent alt ordosunda sinıflandırılmışlardır. CD-P4 ve CD-P3 ise şişme özelliğindeki killerin miktarı çok fazla olması (profil boyunca \% 50 ve daha fazla), kurak mevsimlerde yüzeyden derinlere uzanan çatlaklara sahip olmaları ve profil içerisinde yer yer kayma yüzeylerinin görülmesi nedeni ile Vertisol ordosuna yerleştirilmiştir. Ustic nem rejiminden dolayı ustert alt ordosunda, Haplustert büyük grubuna ait tüm özellikleri taşımaları nedeniyle Typic Haplustert alt grubuna yerleştirilmiştir.

Çizelge 1. Kesit üzerinde yer alan toprakların sınıflaması, fizyografya, arazi kullanım, yükseklik ve bazı fiziko-kimyasal analiz sonuçları

\begin{tabular}{|c|c|c|c|c|c|c|c|c|c|c|c|c|}
\hline \multirow[t]{2}{*}{ Horizon } & \multirow{2}{*}{$\begin{array}{l}\text { Derinlik } \\
\text { (cm) }\end{array}$} & \multirow[t]{2}{*}{$\mathrm{pH}$} & \multirow{2}{*}{$\begin{array}{c}\text { EC } \\
\text { dS.m }{ }^{-1}\end{array}$} & \multirow{2}{*}{$\begin{array}{c}\text { Kireç } \\
\%\end{array}$} & \multirow{2}{*}{$\begin{array}{l}\mathrm{O} . \mathrm{M} \\
\%\end{array}$} & \multicolumn{3}{|c|}{$\begin{array}{l}\text { Değişebilirler Katyonlar } \\
\left(\mathrm{cmol.kg}^{-1}\right)\end{array}$} & \multicolumn{4}{|c|}{$\begin{array}{c}\text { Bünye } \\
\%\end{array}$} \\
\hline & & & & & & $\mathrm{Na}^{+}$ & $\mathrm{K}^{+}$ & $\mathrm{Ca}^{++}+\mathrm{Mg}^{++}$ & Kil & Silt & Kum & Sinif \\
\hline \multicolumn{13}{|c|}{ CD-P4 / Typic Haplustert / Taban / Kuru Tarım / 25 m } \\
\hline Ap & $0-23$ & 7.50 & 0.17 & 0.20 & 1.65 & 0.22 & 1.67 & 40.91 & 56.2 & 23.1 & 20.7 & $\mathrm{C}$ \\
\hline Bss1 & $23-65$ & 7.30 & 0.44 & 0.98 & 1.26 & 0.25 & 1.47 & 39.64 & 62.6 & 12.8 & 24.5 & $\mathrm{C}$ \\
\hline Bss2 & $65-106$ & 8.25 & 0.17 & 1.10 & 1.09 & 1.33 & 1.41 & 37.59 & 68.4 & 15.8 & 15.8 & $\mathrm{C}$ \\
\hline $\mathrm{C}$ & $106+$ & 8.14 & 0.11 & 2.67 & 0.14 & 1.35 & 1.40 & 36.04 & 78.4 & 2.8 & 18.8 & $\mathrm{C}$ \\
\hline \multicolumn{13}{|c|}{ AB-P4 / Lithic Ustorthent /Alt Yamaç / Orman / 42 m } \\
\hline Ap & $0-24$ & 7.87 & 0.55 & 0.49 & 2.35 & 0.41 & 0.28 & 42.24 & 32.1 & 27.9 & 40.1 & $\overline{\mathrm{CL}}$ \\
\hline $\mathrm{Cr}$ & $24+$ & 8.04 & 0.10 & 0.29 & 0.55 & 1.03 & 0.15 & 14.20 & 17.2 & 17.1 & 65.7 & SL \\
\hline \multicolumn{13}{|c|}{ CD-P3 / Typic Haplustert /Etek / Mera /132 m } \\
\hline A & $0-12$ & 7,05 & 0.16 & 0.79 & 1.71 & 0.35 & 0.24 & 40.17 & 41.5 & 24.2 & 34.3 & $\mathrm{C}$ \\
\hline Bss1 & $12-48$ & 7.72 & 0.19 & 0.29 & 1.69 & 0.74 & 0.31 & 48.07 & 68.5 & 18.3 & 13.2 & C \\
\hline Bss2 & $48-89$ & 7.79 & 0.34 & 1.37 & 0.59 & 1.31 & 0.41 & 47.25 & 49.8 & 26.4 & 23.9 & $\mathrm{C}$ \\
\hline $\mathrm{C}$ & $89+$ & 7.96 & 0.30 & 1.18 & 0.17 & 1.26 & 0.24 & 32.84 & 40.3 & 34.2 & 25.5 & $\mathrm{C}$ \\
\hline \multicolumn{13}{|c|}{ CD-P2 / Lithic Ustorthent/ Üst Yamaç / Mera / 185 m } \\
\hline A & $0-16$ & 7.03 & 0.19 & 0.50 & 2.25 & 0.28 & 1.02 & 33.16 & 34.4 & 25.5 & 40.1 & $\mathrm{CL}$ \\
\hline $\mathrm{Cr}$ & $16+$ & 6.93 & 0.25 & 0.20 & 0.42 & 0.45 & 1.24 & 9.39 & 17.1 & 8.4 & 74.5 & SL \\
\hline
\end{tabular}

EC: Elektriksel iletkenlik, OM: Organik madde, C: Kil, Si: Silt, S: Kum

\section{Toprakların Biyolojik Özellikleri}

Toprakların $\beta$-glikosidaz enzim aktivitesinin belirlenmesi amacıyla yüzey ve yüzey altı toprak örnekleri alınmıştır. Bu amaçla $\beta$-glikosidaz enzim aktivitesi 3 tekerrürlü olarak yürütülmüş olup bu analize ait sonuçlar Çizelge 2'de verilmiştir. Topraktaki biyolojik aktivitenin büyük bir kısmı enzimlerin aktivitelerinin ölçülmesiyle belirlenmektedir. Toprakların biyolojik özelliklerinden biri olan $\beta$-glikosidaz enzim aktivitesi de toprakta kükürt döngüsünde rol alan bir enzimdir.

Güneybatı-Kuzeydoğu kesiti üzerinde açılan profillerden alınan toprak örneklerinin $\beta$-glikosidaz enzim aktivitesinin 4.9-98.9 $\mu \mathrm{g}$ p-nitrofenol $\mathrm{g}^{-1} \mathrm{kuru}$ top. arasında değiștiği belirlenmiştir. Analiz sonuçları değerlendirildiğinde Güneybatı-Kuzeydoğu hattı boyunca alınan toprak örneklerinde $\beta$-glikosidaz enzim aktivitesinin genellikle üst toprak katlarında alt toprak katlarına göre daha yüksek olduğu, yani üst toprakta daha yoğun bir mikroorganizma aktivitesinin bulunduğu saptanmıștır. CD-P3 ve AB-P4 no'lu profillerin yüzey horizonunda alt toprak horizonlarına göre daha yüksek $\beta$-glikosidaz enzim aktivitesi belirlenmiştir (Çizelge 2). Bu durum ise üst toprakta daha fazla miktarda bulunan organik maddenin mikroorganizmalar tarafından besin ve enerji kaynağı olarak kullanılması ile ilgilidir. Bu nedenle toprak içerisindeki mikrobiyal 
toplulukların çeşitliliği, miktarı ve bileşimi toprak derinliğine bağlı olarak değişmektedir. Toprağın en üst katı olan A horizonu; mikroorganizma ve solucan gibi canlıların daha yoğun olarak yaşadığı katman olmakla beraber genellikle bitkisel kökenli organik artıkların ayrışması ile oluşmuştur. Dolayısıyla üst toprak katmanları organik madde bakımından daha zengindir (Sposito, 1989). Böylece toprak organik maddesi toprak mikroorganizmalarına enerji sağlayarak mikrobiyal popülasyonu ve aktivitelerini artırmaktadır. CDP4 no'lu profilde ise $\beta$-glikosidaz enzim aktivitesinin yüzey horizonunda alt katlara göre daha düşük olduğu saptanmıştır. Bunun nedeni ise CD-P4 no'lu profilin alt toprak derinliklerindeki yüksek kil içeriği ile ilişkilidir. Bu durum kil parçacıklarının geniş yüzey alanları ve negatif elektrik yükleri nedeniyle pozitif yüklü katyonları kendilerine çekerek daha fazla bitki besin maddesi bağlamaları böylece mikroorganizma aktivitesinin artmasıyla açıklanabilir. Ayrıca, Kiss ve ark. (1976) topraktaki mikroorganizmaların ve enzim aktivitelerinin kil-organik madde-enzim kompleksleri şeklinde ve 3 boyutlu şekilde bulunduğunu bildirmektedirler.

Çizelge 2. Güneybatı-Kuzeydoğu kesiti boyunca açllan profillerden alınan toprak örneklerinin $\beta$-glikosidaz enzim aktivitesi özelliklerine ait konsantrasyonlar

\begin{tabular}{lcc}
\hline Horizon & Derinlik $(\mathrm{cm})$ & $\beta$-Glikosidaz Aktivitesi (p-nitrofenol g-1 kuru top.) \\
\hline CD-P4 / Taban & $0-23$ & \\
\hline Ap & $23-65$ & 62,9 \\
Bss1 & & 98,9 \\
\hline AB-P4 / Alt Yamaç & $0-24$ & 35,1 \\
\hline Ap & $24-74$ & 4,9 \\
Cr & & \\
\hline CD-P3/Etek & $0-12$ & 40,7 \\
Bss1 & $12-48$ & 26,5 \\
\hline CD-P2 / Üst yamaç & & 66,8 \\
\hline A & $0-16$ & \\
\hline
\end{tabular}

\section{$\beta$-Glikosidaz Enzim Aktivitesinin Profil, Arazi Kullanımı ve Yükseklik Arasındaki İlişkileri}

Proje kapsamında ele alınan biyolojik analiz sonuçları istatistiksel olarak profiller arası, profillerin arazi kullanımı ve profillerin yükseklikle olan ilișkisi olmak üzere 3 farklı şekilde değerlendirilmiştir. GüneybatıKuzeydoğu kesiti üzerinde yer alan toprakların $\beta$-glikosidaz enzim aktivitelerindeki değişimlere yönelik istatistiksel sonuçlar Çizelge 3'te verilmiştir. ANOVA testi sonucuna göre Güneybatı-Kuzeydoğu hattı boyunca farklı profillerin toprağın biyolojik özelliklerinden $\beta$-glikosidaz enzim aktivitesi üzerine etkisinin $\% 1$ düzeyinde önemli olduğu bulunmuştur $(\mathrm{P}=0.000<0.01)$. DUNCAN testine göre Güneybatı-Kuzeydoğu hattı boyunca en yüksek $\beta$-glikosidaz enzim aktivitesinin sırasıyla CD-P4 ve CD-P2 no'lu profillerde, en düşük $\beta$-glikosidaz enzim aktivitesinin ise sırasıyla AB-P4 ve CD-P3 no'lu profillerde olduğu belirlenmiştir.

Çizelge 3. Güneybatı-Kuzeydoğu kesit üzerinde yer alan toprakların $\beta$-glikosidaz enzim aktivitelerindeki değișimler

\begin{tabular}{lc}
\hline Profiller & Ortalama + Standart Hata \\
\hline CD-P4/Taban & $80.93 \pm 8.97$ \\
AB-P4/Alt Yamaç & $20.01 \pm 7.34$ \\
CD-P2/Üst Yamaç & $66.76 \pm 0.76$ \\
CD-P3/ Etek & $33.60 \pm 3.28$ \\
Önemlilik (P) & 0.00 \\
\hline
\end{tabular}

Güneybatı-Kuzeydoğu kesitinde arazi kullanımı ve $\beta$-glikosidaz enzim aktivitesi arasındaki ilişkiye yönelik basit istatistik analizi (standart sapma) Çizelge 4'te verilmiştir. Güneybatı-Kuzeydoğu hattı boyunca farklı arazi kullanım şekillerinin toprağın biyolojik özelliklerinden $\beta$-glikosidaz enzim aktivitesi üzerine etkisinin önemsiz olduğu bulunmuştur $(\mathrm{P}=0.670>0.05)$.

Çizelge 4. Arazi kullanımı ve $\beta$-glikosidaz enzim aktivitesi arasındaki ilişki

\begin{tabular}{lc}
\hline Arazi Kullanım ve Arazi Örtüsü & Ortalama + Standart Hata \\
\hline Kuru tarım & $80.93+8.97$ \\
Mera & $44.7 \pm 5.90$ \\
Orman & $20.01 \pm 7.34$ \\
Önemlilik (P) & 0.67
\end{tabular}

Güneybatı-Kuzeydoğu üzerinde yer alan toprakların $\beta$-glikosidaz enzim aktivitesi ile yükseklik arasındaki değişimlere yönelik istatistiksel sonuçlar Çizelge 5'te verilmiştir. CD hattı boyunca farklı yüksekliklerin topraktaki $\beta$-glikosidaz enzim aktivitesi üzerine etkisinin \% 1 düzeyinde önemli olduğu bulunmuştur 
$(\mathrm{P}=0.000<0.01)$. Buna göre en fazla $\beta$-glikosidaz enzim aktivitesinin $25 \mathrm{~m}$ yükseklikte, en düşük $\beta$-glikosidaz enzim aktivitesinin ise $132 \mathrm{~m}$ yükseklikte olduğu belirlenmiştir. Buna bağlı olarak yükseklik arttıkça enzim aktivitesinin azaldığı söylenebilir.

Çizelge 5. Güneybatı-Kuzeydoğu kesit üzerinde yer alan toprakların $\beta$-glikosidaz enzim aktivitesi ile yükseklik arasındaki değişimler

\begin{tabular}{lc}
\hline Yükseklik $(\mathrm{m})$ & Ortalama + Standart Hata \\
\hline 25.00 & $80.9 \pm 9.0 \mathrm{a}$ \\
42.00 & $20.0 \pm 7.3 \mathrm{~b}$ \\
132.00 & $33.6 \pm 3.3 \mathrm{~b}$ \\
185.00 & $66.8 \pm 0.8 \mathrm{a}$ \\
Önemlilik (P) & 0.000 \\
\hline
\end{tabular}

\section{Sonuç}

Toprakların enzimatik faaliyetleri değerlendirildiğinde Güneybatı-Kuzeydoğu kesitinden alınan toprak örneklerinde $\beta$-glikosidaz enzim aktivitesinin genellikle üst toprak katlarında alt toprak katlarına göre daha yüksek olduğu, yani üst toprakta daha yoğun bir mikroorganizma aktivitesinin bulunduğu saptanmıștır. Özellikle yüzey toprağında mikroorganizma faaliyetinin yüksek olması üst toprakta daha fazla miktarda bulunan organik maddenin mikroorganizmalar tarafından besin ve enerji kaynağı olarak kullanılması ile ilgilidir. Ayrıca kilin miktar ve çeşidi ile organizma faaliyeti arasında da önemli ilişki olduğu düşünülmektedir. Şöyle ki, kil parçacıklarının geniş yüzey alanları ve negatif elektrik yükleri nedeniyle pozitif yüklü katyonları kendilerine çekerek daha fazla bitki besin maddesi bağlamaları böylece mikroorganizma aktivitesinin artması nedeniyle açıklanabilir. Ayrıca mikroorganizma faaliyetlerinin arazi örtüsü/arazi kullanım ve yükseklik ile arasındaki ilişki incelendiğinde $\beta$-glikosidaz enzim aktivitesi ile arazi örtüsü/arazi kullanımı istatistiksel açıdan önemsiz olarak belirlenirken, $\beta$-glikosidaz enzim aktivitesi ile yükseklik istatistiksel açıdan önemli bulunmuş ve yükseklik arttıkça enzimatik faaliyetlerin azaldığı belirlenmiştir. Karadeniz Bölgesi; ülkemizin diğer bölgeleri gibi birçok jeolojik dönemlerin özelliklerini barındıran bu nedenle oldukça çeşitli kayaç formasyonlarına ve topografik yapıya sahiptir. Bu değişkenlikler bölgede ayrıca iklim, flora ve faunada farklılıklara da neden olmaktadır. Karadeniz bölgesinde yaygın olarak bulunan bazaltik kayaçlar üzerinde gerçekleştirilen bu çalışma, bölgesel düşünüldüğü zaman toprak yapan faktörler açısından son derece zengin çeşitliliğe sahip olduğu görülmektedir.

\section{Teşekkür}

Bu çalışma 2130073 kodlu TUBİTAK TOVAG tarafından desteklenmiştir. Desteklerinden dolayı teşekkür ederiz.

\section{Kaynaklar}

Arcak S, Karaca A, Haktanır K, 1996. Trifluralin'in üreaz ve alkali fosfataz enzim aktiviteleri üzerine etkisi. Tarım-Çevre İlişkileri Sempozyumu, 384-393, Mersin.

Bouyoucos G,J, 1951. A recalibration of hydrometer for making mechanical analysis of soils. Agronomy Journal 43(9): 434-443.

Eivazi F, Tabatabai M A, 1988. Glucosidases and galactosidases in soil. Soil Biology and Biochemistry 20: 601-606.

Frankberger W, T, Dick W, A, 1983. Relationships with enzyme activities and microbial growth and activity indices in soil. Soil Science Society America Journal 47: 945-951.

Jackson M, L, 1958. Soil Chemical Analysis. Englewood Cliffs, New Jersey: Prentice Hall Inc.

Kiss S, Dragan-Bularda M, Radulescu D, 1976. Biological significance of enzymes accumulated in soil. Advances in Agronomy 27: 25-87.

Rhoades J, D, 1986. Cation exchange capacity, chemical and microbiological properties. Methods of Soil Analysis, Part 2Chemical and Microbiological Properties. ASA-SSSA, Madison, Winsconsin, USA. pp. 149-157.

Rowell M, J, Ladd J, N, Paul E, A, 1973. Enzymatically active complexes of proteases and humic and analogues. Soil Biology and Biochemistry 5: 699-703.

Schinner F, 1986. Veröffenlichung der landwirthschaftlich-chemischen budesanstalt linz / Donau. II. Seminar: Die Anwendung enzymatischer und mikrobiologischer Mthoden in der Bodenalyse.

Soil Survey Staff, 1993. Soil Survey Manual, USDA Handbook, Washington D.C., No: 18.

Soil Survey Staff, 1999. Soil Taxonomy. A basic of soil classification for making and interpreting soil survey. USDA Handbook, Washington D.C., No: 436.

Tabatabai M, A, 1982. Soil enzymes. In Methods of Analysis, Part 2-Chemical and Microbiological Properties. $2^{\text {nd }}$ Edition. Page AL. et al (Eds). ASA-SSSA, Madison, Winsconsin, USA. pp. 903-947.

Tate R, L, 1987. Soil enzymes and organic matter transformations. In soil organic matter, biological and ecological effects. Wiley-Interscience Publications, 69-94, New York. 